\title{
Typhoid fever situation and Vi vaccine experience in Asia
}

\author{
D. Leboulleux*, A.K. Dutta**
}

\begin{abstract}
Abstrak
Demam tifoid masih amat sering terjadi di banyak negara di Asia, terutama pada anak-anak, dengan peningkatan masalah resistensi terhadap berbagai antibiotika. Kami mempelajari kembali semua studi tentang suatu vaksin baru, yang sudah dipublikasikan maupun yang belum, yang sudah terdaftar di 11 negara Asia, berisi polisakarida kapsul Vi dari Salmonella typhi, penyebab penyakit ini. Semua aspek vaksin ini, diberikan dalam dosis tunggal $25 \mu \mathrm{g}$ telah diuji di Asia, termasuk efektivitas, imunogenitas dan toleransi, bahkan pada anak kecil di bawah umur 2 tahun, serta proteksi jangka panjang. Dalam suatu penelitian luas di Nepal, pada kelompok individu berusia 5 sampai 44 tahun, didapatkan efektivitas vaksin Vi ini 72\%. Suatu penelitian luas yang disponsori WHO di Indonesia memastikan imunogenitas dan toleransi yang baik, sejak usia 12 bulan. Serokonversi yang baik, >98\%, dan toleransi yang baik, dengan 3 sampai $7 \%$ demam $38^{\circ} \mathrm{C}$, dikonfirmasikan pada penelitian yang tak dipublikasi di Pakistan dan Filipina. Suatu survei 3 tahun tentang orang berusia di atas 8 tahun yang divaksinasi mengkorfimasi hasil dari Afrika Selatan, dan perlunya vaksinasi ulang setelah 3 tahun. Vaksin polisakarida Vi merupakan antigen yang terstandarisasi baik, yang lebih aman daripada vaksin seluruh kuman, amat imunogenik, efektif dalam dosis tunggal parenteral, terutama di daerah yang endemik. Hasil dari penelitian di Asia sebanding dengan yang telah dilakukan di bagian lain dunia dan memastikan bahwa vaksin ini mungkin lebih baik diberikan pada anak berusia 2 tahun atau lebih.
\end{abstract}

\begin{abstract}
Typhoid fever is still highly prevalent in many countries in Asia, particularly in children, with an increasing problem of multi drugresistance. We reviewed all published and unpublished studies of a new vaccine, already registered in 11 countires in Asia, composed of the Vi capsular polysaccharide of Salmonella typhi, the causative agent of the disease. All aspects of the vaccine, given in a single dose of $25 \mu \mathrm{g}$, were tested in Asia, including efficacy, immunogenicity and tolerance, even in young children below 2 years of age, cind long term protection. Efficacy of this Vi vaccine was evaluated at $72 \%$ in a large trial in Nepal, in subjects aged 5 to 44 years. A large trial sponsored by WHO in Indonesia confirmed the good immunogenicity and tolerance, as from 12 months of age. Good seroconversion, $>98 \%$, and good tolerance, with 3 to $7 \%$ of fever $38^{\circ} \mathrm{C}$, were confirmed in unpublished trials in Pakistan and Philippines. A 3 years surveys of vaccinated persons aged more than 8 years confirms the results from South Africa, and the necessity to revaccinate after 3 years. Vi polysaccharide vaccine is a well-standardized antigen that is safer than whole-cell vaccine, highly immunogenic, effective in a single parenteral dose, particularly in highly endemic situation. The results of the studies performed in Asia care comparable to those conducted in other parts of the world and confirm that this vaccines may be favourably used in children 2 years of age or older.
\end{abstract}

\section{INTRODUCTION}

Typhoid fever is contracted when people ingest food or water infected with Salmonella typhi. It is classically recognized by the sudden onset of sustained fever $\left(39-40^{\circ} \mathrm{C}\right)$, severe headache, nausea, abdominal discomfort, hepatosplenomegaly and severe loss of appetite. Two complications, intestinal perforation and haemorrhage, occur in 0.5 to $1 \%$ of cases. In Indonesia, several forms have been described with cerebral dysfunction, delirium and shock ${ }^{1}$. Each year, about 16 to 33 million cases occur around the world, with more than 600,000 deaths $\mathrm{s}^{1,2}$. Typhoid fever remains an important public problem in many developing countries, with an estimated incidence of 540 cases per 100,000 people 3 .

* Pasteur Mérieux Connaught, Lyon France

** Pasteur Mérieux India PVT-LTD
For a long time, inactivated whole-cell vaccines (Ty 21a) were used. However, their large-scale use has been hindered by their high reactogenicity and variable immunogenicity.

In 1989, a new injectable vaccine, Typhim $\mathrm{Vi}^{\circledR}$, produced by Pasteur Mérieux Connaught (Lyon, France), was marketed in France, containing $25 \mu \mathrm{g}$ of highly purified Salmonella typhi (Ty2 strain) Vi capsular polysaccharide. This vaccine can be given in one dose from 2 years of age onward, and provides an excellent immunogenic response ( 80 to $100 \%$ seroconversion) that lasts 3 years. The safety of the Vi vaccine can be assessed from about 20 immunogenicity and efficacy trials, as well as post-marketing surveillance data from 40 countries in which the vaccine is used. Local reactions include pain, with occasional erythema and induration, but these are rarely severe and always transient. Systemic reactions are rare, with fever occurring in less than $1 \%$ of vaccinated 
subjects 4,5 . This $\mathrm{Vi}$ polysaccharide vaccine is now available in 63 countries, including USA and 11 countries in the Asia-Pacific region.

\section{EPIDEMIOLOGICAL SITUATION IN ASIA}

In Asia, in some high endemic countries, the typhoid situation is a cause for concern. Typhoid fever affects mostly young children of about 5 years of age or less $6-8$, and the risk of complications appears to be higher than Western countries 1,9 . Table 1 summarizes recent epidemiological data from various Asian countries and shows that typhoid fever is a crucial public health problem, particularly for young children.

The resistance or multi-resistance of Salmonella typhi strains to antibiotics, mainly ampicillin, co-trimoxazole and chloramphenicol, is an increasing and important problem. Almost all strains isolated from children below 2 years of age in India are resistant to multiple antibiotics 10 , and multidrug-resistant strains account for 50 of all strains in China ${ }^{11}, 75 \%$ to $100 \%$ in recent outbreaks in Vietnam ${ }^{12,13}$, and $50 \%$ to $77 \%$ in Pakistan 14,15. In Metro Manila in the Philippines, from July 1993-April 1994, 252 multidrug-resistant strains were isolated 16 . Drug-resistant strains have also been described in Malaysia11.

Table 1. Epidemiological data in some Asian countries

\begin{tabular}{|c|c|}
\hline Country & Epidemiology \\
\hline Thailand $\mathrm{d}^{17}$ & $\begin{array}{l}\text { Incidence }=12 / 10^{5} . \mathrm{CFR}=1 \% \\
\text { In } 1996 \text { no major problem concerning } \\
\text { resistance to antibiotics }\end{array}$ \\
\hline Pakistan $^{18,19}$ & $\begin{array}{l}\text { 1990-1994: Estimation of } 150,000 \text { cases } \\
\text { per year } 48 \% \text { are }<5 \text { years of age }\end{array}$ \\
\hline Indonesia $^{1.20}$ & $\begin{array}{l}\text { Incidence }=350 \text { to } 810 / 10^{5}, \text { Attack rate of } \\
\text { positive blood culture }=1026 / 10^{5}>20.000 \\
\text { deaths per year. Age }=3 \text { to } 19 \text { years }\end{array}$ \\
\hline $\begin{array}{l}\text { Papua New } \\
\text { Guinea }^{21.2}\end{array}$ & $\begin{array}{l}\text { Incidence }=1208 / 10^{5} . \text { All age groups } \\
\text { affected, mostly in rural areas }\end{array}$ \\
\hline India ${ }^{22}$ & $\begin{array}{l}\text { Incidence }=760 / 10^{5} .<15 \text { years of age. } \\
\text { CFR }=1.1 \%\end{array}$ \\
\hline Philippines ${ }^{23}$ & $\begin{array}{l}\text { Several outbreaks per year in Metro Manila, } \\
850 \text { cases in } 1995\end{array}$ \\
\hline Malaysia $^{24}$ & Incidence $=4.46 / 10^{5} . \mathrm{CFR}=0.88 \%$ \\
\hline
\end{tabular}

\section{VACCINE IN ASIA}

A significant part of the development of the Pasteur Mérieux Connaught Vi vaccine has been conducted in Asia. Efficacy, immunogenicity, long-term protection and safety studies, conducted in 5 different countries, are listed in Table 2.
Vi vaccine is immunogenic in children and adults, with a seroconversion rate $(>4$-fold increase in antibody titer) from 68 to $100 \%$. Post-vaccination antibody titers observed in Asia, measured with PHA or RIA methods, are high and comparable to other studies. Vi Vaccine is well tolerated, with only a 2.6 to 12 $\%$ incidence of fever. Local and general reaction are always mild and transient. In Nepal, in high-endemic situation, $\mathrm{Vi}$ vaccine protected $72 \%$ of vaccines against typhoid injection. In Asia, Vi the vaccine appears safe and immunogenic, and provides a high level of protection.

\section{DISCUSSION}

Recent data confirm that Asia remains an endemic or high-endemic area for typhoid fever with increasing multi-drug resistance of Salmonella typhi strains. Sanitation and improvement in hygiene are necessary measures to control foodborne diseases, but are both costly and long-term. In reponse to this situation, many countries have adopted vaccination strategies. However, the inactivated whole-cell vaccines (Ty 21a) previously used are highly reactive and have variable immunogenicity.

The $\mathrm{Vi}$ vaccine recently manufactured by Pasteur Mérieux Connaught (Typhim Vir) has been developed in Europe and USA. Furthermore, many studies conducted in Asia have also shown that this vaccine is well tolerated and immunogenic, both in children and adults. In addition, this vaccine is particularly efficacious and protective in high-endemic situations and although no strict comparisons have been made, results appear better than those obtained with the encapsulated oral vaccine Ty21 $\mathrm{a}^{20,25}$.

Revaccination is recommended after 3 years, as decribed in studies performed in USA and South Africa, consistent with long-term follow-up results in Korea ${ }^{30,31}$.

All the results generated in Asian studies are consistent with those obtained from trials in other continents. Children from 2 years of age onwards, particularly at school-age, but also working adults, military personnel, exposed persons and foodhandlers are potentially at risk and must be protected. It would be significantly advantageous for both private practitioners and public health authorities in Asia to consider this new Vi vaccine as a useful, immediate and major means of reducing the morbidity and mortality of typhoid fever. 
Table 2. Efficacy, immunogenicity and tolerance data from trials with Typhim Vi vaccine conducted in Asia

\begin{tabular}{|c|c|c|c|}
\hline Country/year & Age/N & Design & Results \\
\hline $\begin{array}{l}\text { Nepal } 1996 \\
\text { Acharya }^{25}\end{array}$ & $\begin{array}{l}5-44 \text { years } \\
\mathrm{N}=69,000\end{array}$ & $\begin{array}{l}\text { efficacy } \\
\text { controls received Pneumo vaccine }\end{array}$ & - $72 \%$ of efficacy after 17 months of follow-up \\
\hline $\begin{array}{l}\text { Nepal } 1986 \\
\text { Acharya }^{25}\end{array}$ & $\begin{array}{l}5-14 \text { years } \\
N=65\end{array}$ & $\begin{array}{l}\text { imunogenicity } \\
\text { tolerance }\end{array}$ & $\begin{array}{l}\text { - } \mathrm{GMT}=1.89 \mu \mathrm{g} / \mathrm{ml}, 77 \%>4 \text {-fold increase (RIA) } \\
\text { - no significant side-effects }\end{array}$ \\
\hline $\begin{array}{l}\text { Nepal } 1986 \\
\text { Acharya }^{25}\end{array}$ & $\begin{array}{l}15-44 \text { years } \\
N=43\end{array}$ & immunogenicity and tolerance & $\begin{array}{l}\text { - GMT - } 3.68 \mu \mathrm{g} / \mathrm{ml} \\
\text { - } 79 \% 4 \text { - fold increase (RIA) } \\
\text { - no significant side-effects }\end{array}$ \\
\hline $\begin{array}{l}\text { Indonesia } \\
1986-90 \\
\text { Simanjuntak }^{26}\end{array}$ & $\begin{array}{l}6-13 \text { months } \\
N=130\end{array}$ & $\begin{array}{l}\text { immunogenicity and tolerance } \\
\text { control group receive } \\
\text { meningococcal vaccine }\end{array}$ & $\begin{array}{l}\text { - } 77 \% \text { with at least } 4 \text {-fold increase after } 28 \text { days. } \\
\text { Peak GMT } 28 \text { days after vaccination }=12.5 \text {-fold } \\
\text { above the baseline GMT (RIA) } \\
\text { - Mild side-effects in both vaccinated and control groups }\end{array}$ \\
\hline $\begin{array}{l}\text { Indonesia } \\
1986-90 \\
\text { Simanjuntak }^{27}\end{array}$ & $\begin{array}{l}1-12 \text { years } \\
\mathrm{N}=268 \\
>21 \text { years } \\
\mathrm{N}=32\end{array}$ & $\begin{array}{l}\text { immunogenicity and tolerance } \\
\text { controls receive pnuemo vaccine } \\
\text { immunogenicity and tolerance } \\
\text { controls receive pneumo vaccine }\end{array}$ & $\begin{array}{l}\text { - } 90 \%>4 \text {-fold increase, GMT } 28 \text { days post-vaccination = } \\
5.03 \mu \mathrm{g} / \mathrm{ml} \text { (RIA) } \\
\text { - local reaction }<15 \% \text {, fever }<3 \% \text {, no severe reaction } \\
\text { - GMT }=11.3 \mu \mathrm{g} / \mathrm{ml}, 68 \% \text {-fold increase } \\
\text { - pain - } 29 \% \text {, fever }=12 \% \text {, no severe reaction }\end{array}$ \\
\hline $\begin{array}{l}\text { Philippines } \\
1991 \\
\text { Montalban }^{28}\end{array}$ & $\begin{array}{l}5-10 \text { years } \\
\mathrm{N}=153\end{array}$ & $\begin{array}{l}\text { immunogenicity and tolerance } \\
47 \text { tested before and after } \\
\text { vaccination }\end{array}$ & $\begin{array}{l}\text { - } 100 \% \text { 4-fold increase, GMT }=79.85 \text { (PHA) } \\
\text { - fever }>38 \% \mathrm{C}=2.6 \% \text {, Mild and transient local reactions, } \\
\text { no severe reaction }\end{array}$ \\
\hline $\begin{array}{l}\text { Pakistan } 1988 \\
\text { Waheed }^{29}\end{array}$ & $\begin{array}{l}2-10 \text { years } \\
\mathrm{N}=200\end{array}$ & $\begin{array}{l}\text { immunogenicity and tolerance } \\
158 \text { infants completed the study }\end{array}$ & $\begin{array}{l}\text { - } 98,7 \% \text { seroconversion, } \mathrm{GMT}=24,5(\mathrm{PHA}) \\
\text { - } 4.6 \% \text { local reaction, } 7.2 \% \text { fever }>38^{\circ} \mathrm{C} \text {, transient }\end{array}$ \\
\hline $\begin{array}{l}\text { Korea 1991-93 } \\
\text { Kim }^{30}\end{array}$ & $\begin{array}{l}8-16 \text { years } \\
N=64\end{array}$ & $\begin{array}{l}\text { immunogenicity } \\
3 \text { years follow-up }\end{array}$ & $\begin{array}{l}\text { - > } 4 \text {-fold increase }=98 \% \text { at } 1 \text { month, } 100 \% \text { at } 3 \text { months } \\
\text { GMT }=69.4 \text { and } 49.2 \text { respectively (PHA) } \\
\text { mean increases }=28.6 \text {-fold and } 20.2 \text {-fold, respectively }\end{array}$ \\
\hline $\begin{array}{l}\text { Korea 1991-93 } \\
\text { Kim }^{30}\end{array}$ & $\begin{array}{l}20-28 \text { years } \\
\mathrm{N}=85\end{array}$ & $\begin{array}{l}\text { immunogeniticity } \\
3 \text { years follow-up }\end{array}$ & $\begin{array}{l}\text { - }>4 \text {-fold increases }=88 \% \text { at } 1 \text { month, } 96 \% \text { at } 3 \text { months } \\
\text { GMT }=79.1 \text { and } 120.3 \text { respectively (PHA) } \\
\text { mean increases }=11.9 \text { fold and } 18.1 \text {-fold respectively }\end{array}$ \\
\hline
\end{tabular}

GMT: geometric mean titer

PHA: passive hemagglutination method

RIA: radio-immuno assay method

\section{REFERENCES}

1. Ivanoff $\mathrm{B}$, Levine MM, Lambert PH. Vaccination against typhoid fever present status. Bulletin WHO 1994; 72: 957-71.

2. Pang T and al. Typhoid fever and other salmonellosis: a continuing challenge. Trends in Microbiology 1995; 3(7): 253-5.

3. Edelman R, Levine MM. Summary of an international workshop on typhoid fever. Rev Infect Dis 1986; 8: 329-49.

4. Plotkin S, Bouveret-Le Cam N. A new typhoid vaccine composed of the Vi capsular polysaccharide. Arch Intern Med 1995; 155: 2293-9.

5. Klugman K. Second Asia-Pacific symposium on typhoid fever and other salmonellosis. Abstract book Thailand 1994; 83

6. Mahle T, Levine MM. Salmonella typhi infection in children younger than five years of age. Pediatr Infect Dis J 1993; 12 : 627-31.
7. Pandey KK, Srinavasan S, Mahadevan S, Nalini P, Sambasiva Rao R. Typhoid fever below five years. Indian Pediatr 1990; 27: 153-6.

8. Kapoor JP, Mohan M, Talwar V, Darai TS, Bhargava SK. Typhoid fever in young children. Indian Pediatr 1985; 22: 8113.

9. Butler T, Islam A, Kabir I, Jones PK. Patterns of morbidity and mortality in typhoid fever dependant on age and gender: Review of 552 hospitalized patients with diarrhea. Rev Infect Dis 1991; 13: 85-90

10. Gupta A, Jalla S, Bhan MK. Advances in vaccines for typhoid fever. Indian J Pediatr 1994; 61: 321-39.

11. Sakaguchi S, Sakaguchi T, Arai T. Genetic similarity of R plasmids from Salmonella Typhi strains isolated in various countries. Second Asia-Pacific symposium on Typhoid fever and other Salmonellosis, South East Asian. J Trop Med 
Public Health 1995; 26(2): 33-6.

12. Typhoid fever. WHO Fact Sheet 1997; 149.

13. Dr Wainer. Personal communication, Wellcome Foundation HCMC.

14. Bhutta ZA, Khan IA, Molla AM. Therapy of multidrug resistant typhod fever with oral cefixime vs intravenous ceftriaxone. Pediatr Infect Dis J 1994; 13: 990-4.

15. Mirza SH, Beeching NJ, Hart CA. The prevalence and clinical features of multi-drug resistant Salmonella Typhi infections in Baluchistan, Pakistan. Annals of Tropical Medicine and Parasitology 1995; 89(5): 515-9.

16. Saniel M. Multi-drug resistant typhoid fever in Metro Manila, the Philippines: Epidemiologic highlights of an outbreak. Official Proceedings to the $4^{\text {th }}$ Wes Pac Congress Chem \& In Di, Suppl to JAMA SE Asia 1994; 110(10): 32832.

17. Unpublished data from Division of Epidemiology of MOPIL, Thailand.

18. Luby S. Personal communication. Unpublished.

19. Internal source PMCI.

20. Simanjuntak $\mathrm{C}$, and al. Oral Immunization against typhoid fever in Indonesia with Ty2la Vaccine. Lancet 1991; 338: 1055-9.

21. Passey M, Suve N, Taime J, Clegg A, Ivivi R, Javati A, Joannes M, Karagifa K, Kave H, Kave P, Kirmin S, Lupiwa S, Namuigi P, Alpers M. Highly endemic typhoid fever in Papua New Guinea. Second Asia-Pacific symposium on Typhoid Fever and Other Salmonellosis, South East Asian J Trop Med Public Health 1995; 26(2): 83-4.
22. IChpujani RL, Bhatia R. Typhoid fever, First edition Top Publications, Delhi 1997.

23. Internal source-PMCI.

24. Annual Report of Ministry of Health, Malaysia 1995.

25. Acharya IL, and al. Prevention of typhoid fever in Nepal with the Vi capsular polysaccharide of Salmonella Typhi. New England J of Med 1987; 317: 1101-4.

26. Simanjuntak and al. Side effects and response of a parenteral Vi-capsular polysaccharide vaccine in Indonesian infants aged 6-12 months. Second Asia-Pacific symposium on Typhoid Fever and Other Salmonellosis, South East Asian J Trop Med Public Health 1995; 26(2): 275.

27. Simanjuntak C. Safety and immunogenicity study of Vi polysaccharide typhoid vaccine in Indonesia children and adults. Abstracts to be submitted.

28. Montalban C, Cruz B, Cruz A. Evaluation of the șafety and immnogenicity of Vi CPS typhoid vaccine in 5-10 years old Filipino children. XIII't International Congress for Tropical Medicine and Malaria, Pattaya Thailand 1992.

29. Waheed A. Safety and immunogenicity of Vi typhoid vaccine in 2 to 10 years old children. Abstract to be submitted, internal source PMCI.

30. Kim YR, and al. Immunogenicity of Vi capsular Polysaccharide (CPS) vaccine up to 3 years in Korea. Abstract not yet published, internal source PMCI.

31. Tacket CO, Levine MM, Robbins JB. Persistence of antibody titres three years after vaccination with polysaccharide vaccine against typhoid fever. Vaccine 1988; 6: 307-8. 